\title{
Low serum sodium level during cardiopulmonary bypass predicts increased risk of postoperative stroke after coronary artery bypass graft surgery
}

\author{
Elizandro Munoz III, MD, ${ }^{a}$ Holly Briggs, BS, ${ }^{b}$ Daniel A. Tolpin, MD, ${ }^{c}$ Vei-Vei Lee, MS, ${ }^{\mathrm{d}}$ Terry Crane, BS, \\ MacArthur A. Elayda, MD, PhD, ${ }^{\mathrm{d}}$ Charles D. Collard, MD, ${ }^{\mathrm{c}}$ and Wei Pan, $\mathrm{MD}^{\mathrm{c}}$
}

\begin{abstract}
Objective: Rapid decreases in serum sodium levels are associated with altered mental status, seizures, and coma. During cardiac surgery, serum sodium levels decrease rapidly when cardiopulmonary bypass is initiated because cardiopulmonary bypass causes hemodilution. However, whether this decrease influences neurologic outcome after cardiac surgery remains unclear. We investigated whether the average serum sodium level during cardiopulmonary bypass is independently predictive of postoperative stroke or 30-day all-cause mortality in patients who undergo primary coronary artery bypass grafting.
\end{abstract}

\begin{abstract}
Methods: In a single-institution, retrospective cohort of 2348 consecutive patients who underwent primary, isolated coronary artery bypass grafting, sequential multivariate logistic regression was performed to determine the threshold below which the average serum sodium level during cardiopulmonary bypass independently predicts postoperative stroke or early death. To further test the validity of this threshold and to control for selection bias, stepwise multivariate logistic regression was also performed on propensity score-matched patients $(n=924)$.

Results: An average serum sodium level less than $130 \mathrm{mEq} / \mathrm{L}$ during cardiopulmonary bypass was independently predictive of stroke, both in the entire study cohort $(1.44 \%$ vs $2.92 \%$; odds ratio, $2.09 ; 95 \%$ confidence interval, $1.1-4.1 ; P=.03)$ and in the propensity-matched patients $(0.9 \%$ vs $3.0 \%$; odds ratio, $4.1 ; 95 \%$ confidence interval, $1.3-13.0 ; P=.02$ ). The average serum sodium level during cardiopulmonary bypass was not independently associated with early death, regardless of what threshold value was used.
\end{abstract}

Conclusions: An average serum sodium level of less than $130 \mathrm{mEq} / \mathrm{L}$ during cardiopulmonary bypass is independently associated with an increased risk of postoperative stroke in patients who undergo primary coronary artery bypass grafting. (J Thorac Cardiovasc Surg 2014;147:1351-5)

The incidence of postoperative stroke after coronary artery bypass grafting (CABG) is between $1 \%$ and $3 \%$. This complication is associated with significant morbidity and mortality, as well as increased treatment costs. ${ }^{1-4}$ Although the cause of neurologic insult after CABG is probably multifactorial, current theories principally attribute it to 3 mechanisms: cerebral emboli (eg, aortic manipulation), hypoperfusion during cardiopulmonary bypass (CPB), and increases in metabolic demand in neural tissue already exposed to relative ischemia. ${ }^{5-10}$ In the present study, we hypothesized that an abrupt decrease

\footnotetext{
From the Department of Anesthesiology ${ }^{\mathrm{a}}$ and the Medical School, ${ }^{\mathrm{b}}$ Baylor College of Medicine, Houston, Tex; the Divisions of Cardiovascular Anesthesiology ${ }^{\mathrm{c}}$ and Biostatistics and Epidemiology, ${ }^{\mathrm{d}}$ Texas Heart Institute, Houston, Tex; and the School of Perfusion Technology, ${ }^{\mathrm{e}}$ Texas Heart Institute, Houston, Tex.

All support was provided solely by institutional or departmental sources.

Disclosures: Authors have nothing to disclose with regard to commercial support.

Received for publication March 25, 2013; revisions received Aug 29, 2013; accepted for publication Sept 17, 2013; available ahead of print Nov 4, 2013.

Address for reprints: Wei Pan, MD, Division of Cardiovascular Anesthesiology,

Texas Heart Institute, 6720 Bertner Ave, Room 0520, Houston, TX 77030

(E-mail: wpan@texasheart.org).

$0022-5223 / \$ 36.00$

Copyright (c) 2014 by The American Association for Thoracic Surgery

http://dx.doi.org/10.1016/j.jtcvs.2013.09.034
}

in sodium levels during $\mathrm{CPB}$ may also contribute to the risk of postoperative stroke after CABG.

Rapid decreases in serum sodium levels have been associated with altered mental status, seizures, and coma in nonsurgical patients. $^{11,12}$ Likewise, sudden rapid decreases in serum sodium levels may occur secondary to hemodilution when $\mathrm{CPB}$ is initiated during cardiac surgery. ${ }^{13}$ Warwick and colleagues ${ }^{13}$ showed that the degree of change in serum sodium level is linearly related to the size of the patient, the preoperative hemoglobin level, and the circuit prime volume. However, the influence of serum sodium level during CPB on neurologic outcome after cardiac surgery remains unclear. The aim of this study was to investigate whether the average serum sodium level during CPB is independently associated with an increased risk of postoperative stroke or early (30-day all-cause) mortality in patients who undergo primary CABG.

\section{MATERIALS AND METHODS Patients}

After institutional review board approval was obtained, a retrospective cohort study was performed on all patients $(\mathrm{N}=2348)$ who underwent primary, isolated CABG with CPB between January 2004 and December 2007 at the Texas Heart Institute at St Luke's Episcopal Hospital (Houston, Tex). 


$$
\begin{aligned}
& \text { Abbreviations and Acronyms } \\
& \begin{aligned}
\text { CABG } & =\text { coronary artery bypass grafting } \\
\text { CI } & =\text { confidence interval } \\
\mathrm{CPB} & =\text { cardiopulmonary bypass } \\
\mathrm{OR} & =\text { odds ratio }
\end{aligned}
\end{aligned}
$$

Preoperative variables of interest included patient demographics, medical history, preoperative medications, and risk factors.

\section{Data Measurement and Outcome Variables}

The CPB machine prime consisted of 1200 to $1400 \mathrm{~mL}$ of lactated Ringer's solution with mannitol ( $25 \mathrm{~g}$ ). For each patient, the serum sodium level was measured at 15 -minute intervals during $\mathrm{CPB}$. The average serum sodium level during CPB was then calculated for each patient.

The incidence of postoperative stroke and early death was abstracted from the Texas Heart Institute cardiac surgical database. A diagnosis of stroke was made if there was clinical evidence of a new focal or global deficit that was confirmed by computed tomography or magnetic resonance imaging. Early death was defined as documented death within 30 days of surgery.

\section{Statistics}

All statistical analyses were performed with SAS statistical software (v 9.1, SAS Institute, Inc, Cary, NC) by the Division of Biostatistics and Epidemiology at the Texas Heart Institute. Categoric (frequency) variables were expressed as percentages, and continuous variables were expressed as the mean \pm standard deviation. Preoperative demographic variables and risk factors were compared between groups by using univariate (chisquare) analysis for categoric data and multivariate linear regression analysis for continuous numeric data. To determine the threshold at which the average sodium level during CPB independently predicts stroke or early death, sequential multivariable logistic regression analyses were performed in which the threshold for average sodium level was adjusted by $5-\mathrm{mEq} / \mathrm{L}$ increments over a range 125 to $145 \mathrm{mEq} / \mathrm{L}$. Odds ratios (ORs) and $95 \%$ confidence intervals (CIs) are reported.

To control for selection bias, patients were divided into 2 groups according to whether their serum sodium level was above or below the threshold identified in the serial logistic regression analyses. Then, using data from 27 variables (Table 1), we calculated propensity scores for each patient and matched patients $1: 1$ between the 2 groups.

\section{RESULTS}

A total of 2348 patients were enrolled. Of these, 137 were not included in the analysis because they had missing data in 1 or more of the 45 required perioperative variables. The average sodium level during CPB was then determined for each of the remaining 2211 patients. The distribution of patients by average sodium level during CPB is shown in Figure 1. Sequential multivariable logistic regression analyses were then performed to determine the threshold at which the average sodium level during CPB was independently associated with an increased risk of stroke or early death.

Postoperative stroke occurred in 39 patients $(1.9 \%)$, and early death occurred in 44 patients $(2.0 \%)$. An average sodium level less than $130 \mathrm{mEq} / \mathrm{L}$ during CPB was independently associated with an increased risk of postoperative stroke $(2.92 \%$ vs $1.44 \%$; OR, $2.1 ; 95 \%$ CI, $1.1-4.1$; $P=.03)$. Fourteen of the 480 patients $(2.92 \%)$ with an average sodium level less than $130 \mathrm{mEq} / \mathrm{L}$ during CPB had a postoperative stroke evidenced by computed tomography or magnetic resonance imaging, whereas 25 of the 1731 patients $(1.44 \%)$ with an average sodium level 130 $\mathrm{mEq} / \mathrm{L}$ or greater during $\mathrm{CPB}$ had such a stroke. Other average sodium levels during $\mathrm{CPB}$ were not associated with increased risk of postoperative stroke (Figure 2). In contrast, the average serum sodium level during CPB was not independently associated with early death at any threshold. Of the 14 patients with an average sodium level during CPB less than $130 \mathrm{mEq} / \mathrm{L}$ who had a stroke, 10 manifested neurologic deficits within 2 days of surgery, and 2 had early mortality. Other independent predictors of postoperative stroke included age greater than 65 years $(\mathrm{OR}, 2.8$; $95 \% \mathrm{CI}, 1.3-6.0 ; P=.01)$ and a history of peripheral vascular disease (OR, 3.7; 95\% CI, 1.9-7.1; $P<.001)$.

To further control for selection bias, stepwise multivariate logistic regression was performed on the propensity score-matched patients $(\mathrm{n}=924$; Table 1$)$ who were grouped by whether their average sodium level during CPB was above or below the threshold value of $130 \mathrm{mEq} / \mathrm{L}$. There were no significant differences between groups (ie, $<130$ vs $\geq 130 \mathrm{mEq} / \mathrm{L}$ ) with respect to any variable. Moreover, the preoperative serum sodium level before CPB did not significantly differ between groups $(141 \pm 2.4 \mathrm{mEq} / \mathrm{L}$ in $\mathrm{Na}<130$ vs $138 \pm 2.8 \mathrm{mEq} / \mathrm{L}$ in $\mathrm{Na} \geq 130$ ). After propensity matching, an average serum level less than $130 \mathrm{mEq} /$ L during CPB was still independently associated with an increased risk of postoperative stroke compared with an average sodium level of $130 \mathrm{mEq} / \mathrm{L}$ or greater $(0.9 \%$ vs $3.0 \%$; OR, 4.1 ; $95 \%$ CI, 1.3-13.0; $P=.02$; Figure 3).

\section{DISCUSSION}

Previous studies have shown that intraoperative aortic manipulation and hypoperfusion during $\mathrm{CPB}$ are associated with increased risk of postoperative stroke after cardiac surgery. ${ }^{5-8}$ Our results suggest that an average sodium level during CPB less than $130 \mathrm{mEq} / \mathrm{L}$ is also an independent risk factor for postoperative stroke, indicating a greater than 2-fold increase in risk. This was true both in our complete patient cohort and in our propensity-matched subgroups. These data suggest a potential novel mechanism for postoperative stroke after cardiac surgery.

There are several potential mechanisms by which hyponatremia may be associated with postoperative stroke. First, central nervous system osmotic swelling may result from an acute decrease in serum sodium levels during CPB. Acute swelling may disrupt the myelin sheath and cause neuronal rupture. ${ }^{14}$ Second, acute swelling may also result in increased intracranial pressure and decreased cerebral perfusion pressure. ${ }^{14-16}$ Kvalheim and colleagues ${ }^{16}$ noted a net fluid gain of $116 \mathrm{~mL} / \mathrm{kg}$ and an increase in intracranial 
TABLE 1. Perioperative demographics and risk factors in propensity score-matched patients

\begin{tabular}{|c|c|c|c|}
\hline & {$[\mathrm{Na}]<130 \mathrm{mEq} / \mathrm{L}(\mathrm{n}=462)$} & {$[\mathrm{Na}] \geq 130 \mathrm{mEq} / \mathrm{L}(\mathrm{n}=462)$} & $P$ value \\
\hline Age $>65$ y $(\%)$ & 49.8 & 50.0 & .95 \\
\hline Female gender $(\%)$ & 21.4 & 24.7 & .24 \\
\hline BMI, $\mathrm{kg} / \mathrm{m}^{2}($ mean $\pm \mathrm{SD})$ & $28.3 \pm 5.0$ & $28.9 \pm 6.0$ & .10 \\
\hline Preoperative $[\mathrm{Na}]<135 \mathrm{mEq} / \mathrm{L}(\%)$ & 65.2 & 65.2 & 1.00 \\
\hline Preoperative GFR $<60 \mathrm{~mL} / \mathrm{min} / 1.73 \mathrm{~m}^{2}(\%)$ & 29.0 & 30.7 & .57 \\
\hline Average serum hemoglobin level during $\mathrm{CPB}, \mathrm{g} / \mathrm{dL}$ (mean $\pm \mathrm{SD}$ ) & $7.9 \pm 1.0$ & $8.0 \pm 1.0$ & .16 \\
\hline Transient ischemic attack $(\%)$ & 4.3 & 3.0 & .29 \\
\hline History of stroke $(\%)$ & 6.7 & 8.0 & .45 \\
\hline Diabetes $(\%)$ & 8.4 & 10.4 & .31 \\
\hline Hypertension $(\%)$ & 84.4 & 83.8 & .78 \\
\hline Smoking $(\%)$ & 53.7 & 52.0 & .6 \\
\hline Pulmonary disease $(\%)$ & 34.0 & 33.8 & .94 \\
\hline Preoperative beta-blocker use $(\%)$ & 54.7 & 49.7 & .13 \\
\hline Preoperative statin use $(\%)$ & 64.0 & 59.7 & .18 \\
\hline Prior myocardial infarction $(\%)$ & 40.5 & 39.6 & .79 \\
\hline Congestive heart failure $(\%)$ & 23.4 & 22.5 & .75 \\
\hline NYHA class III or IV (\%) & 53.0 & 57.1 & .21 \\
\hline Ejection fraction $<50 \%(\%)$ & 32.7 & 30.7 & .52 \\
\hline Unstable angina $(\%)$ & 48.5 & 45.5 & .36 \\
\hline Left main CAD (\%) & 31.8 & 32.0 & .94 \\
\hline 3-vessel CAD (\%) & 61.0 & 59.7 & .7 \\
\hline Urgent surgery $(\%)$ & 33.1 & 31.4 & .57 \\
\hline Previous valvular surgery (\%) & 7.4 & 8.7 & .47 \\
\hline Peripheral vascular disease $(\%)$ & 18.8 & 19.7 & .74 \\
\hline Preoperative use of IABP $(\%)$ & 5.0 & 5.0 & 1.00 \\
\hline Crossclamp time, $\min ($ mean $\pm \mathrm{SD})$ & $39.5 \pm 21.6$ & $41.5 \pm 24.7$ & .12 \\
\hline Total bypass time, $\min ($ mean \pm SD) & $66.5 \pm 34.7$ & $69.1 \pm 35.4$ & .27 \\
\hline
\end{tabular}

$B M I$, Body mass index; $C A D$, coronary artery disease; $C P B$, cardiopulmonary bypass; GFR, glomerular filtration rate; IABP, intra-aortic balloon pump; NYHA, New York Heart Association; $S D$, standard deviation.

pressure of approximately $5 \mathrm{~mm} \mathrm{Hg}$ after 150 minutes of hypothermic CPB in a porcine model. Likewise, Ayus and colleagues ${ }^{17}$ found an increase in total brain water after 2 hours of relative hyponatremia in rodents. However, the pathophysiology of stroke associated with hyponatremic CPB may go beyond simple osmotic swelling of neural tissue and reductions in cerebral perfusion pressure. A third, less well known, potential mechanism is linked to increased

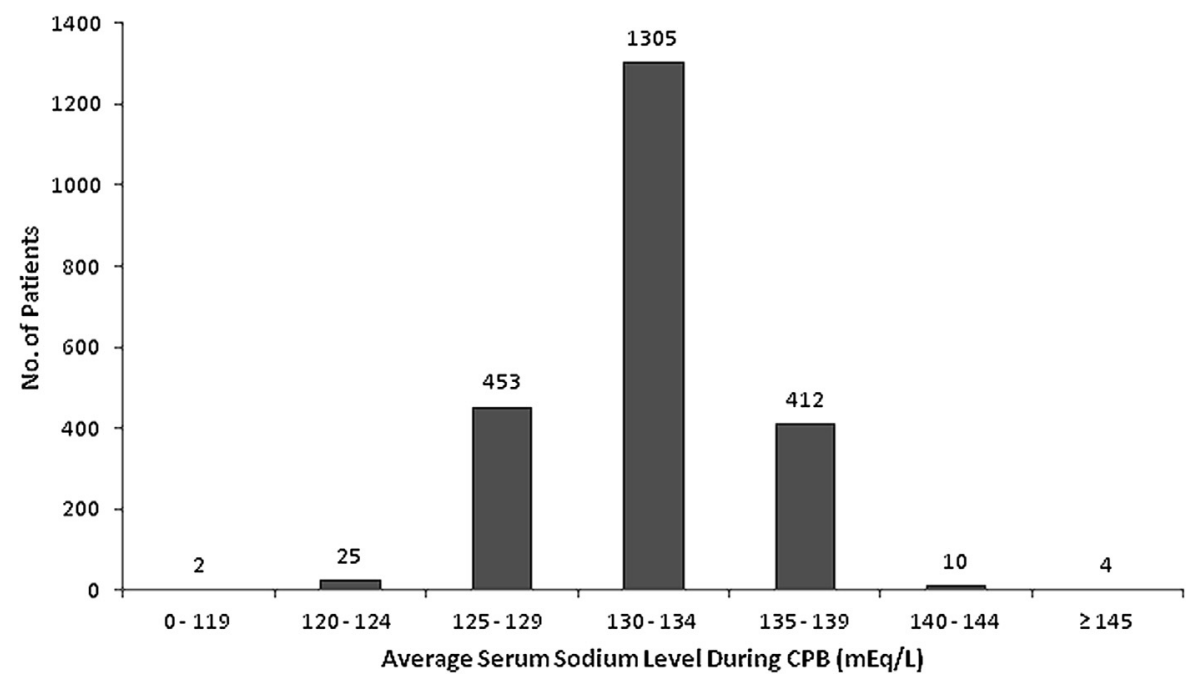

FIGURE 1. Distribution of patients by average sodium level during CPB. $C P B$, Cardiopulmonary bypass. 


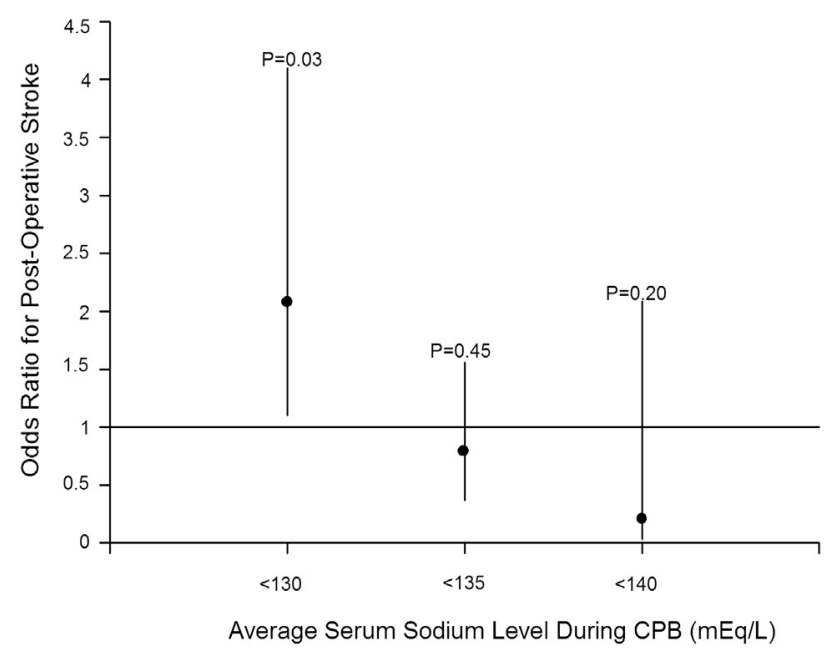

FIGURE 2. ORs and $95 \%$ CIs for the incidence of postoperative stroke at each average serum sodium threshold level during CPB. CPB, Cardiopulmonary bypass.

neuronal $\mathrm{Na}^{+}-\mathrm{K}^{+}$adenosine triphosphatase activity as cells work to increase extrusion of sodium to mitigate swelling. ${ }^{17-19}$ Histologic examination of a rodent model has shown that this strained metabolic balance is further taxed during periods of relative hypoxia, which in turn results in further neural swelling and necrotic cell damage. ${ }^{17}$ Indeed, Ayus and colleagues ${ }^{17}$ showed that cytotoxic damage and mortality were greater in the presence of both relative hyponatremia and hypoxia than either alone.

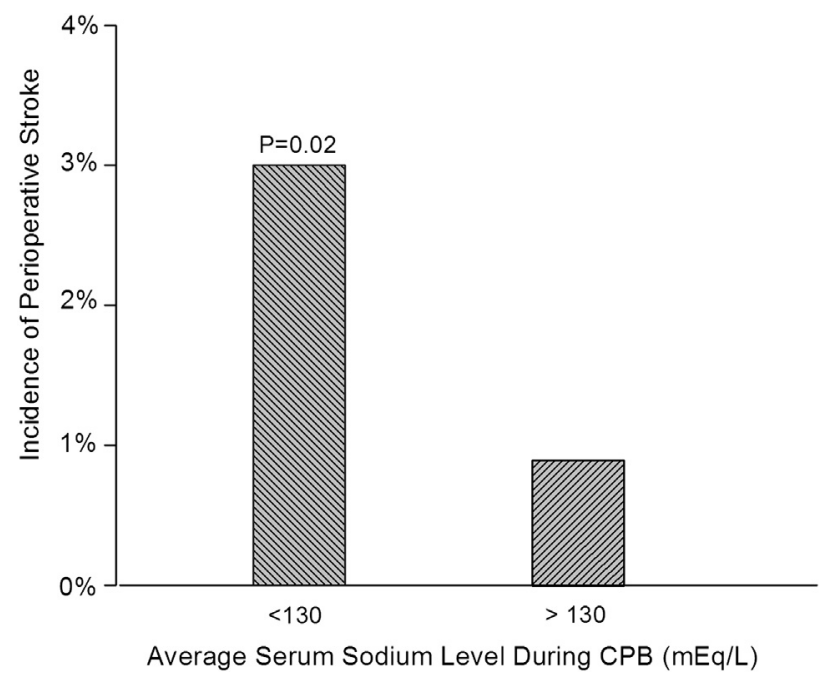

FIGURE 3. Incidence of postoperative stroke in propensity-matched patients who underwent primary $\mathrm{CABG}$ with $\mathrm{CPB}$. After propensity matching, an average serum sodium level less than $130 \mathrm{mEq} / \mathrm{L}$ during $\mathrm{CPB}$ was still independently associated with an increased risk of postoperative stroke compared with an average sodium level $130 \mathrm{mEq} / \mathrm{L}$ or greater $(0.9 \%$ vs $3.0 \%$; OR, $4.1 ; 95 \%$ CI, $1.3-13.0 ; P=.02)$. CPB, Cardiopulmonary bypass.
Of note, 10 of the 14 patients with an average serum sodium level less than $130 \mathrm{mEq} / \mathrm{L}$ during $\mathrm{CPB}$ who had a postoperative stroke manifested neurologic deficits within 2 days of surgery, which suggests an acute insult.

It is important to note that although data regarding the effects of hyponatremia during CPB with respect to human neurologic injury are currently lacking, the current study's findings are significant in that sodium levels of less than $130 \mathrm{mEq} / \mathrm{L}$ are not uncommon during CPB. Although current perfusion practice does not mandate maintaining serum sodium levels during CPB above a certain average threshold, further research may be needed to determine whether such a policy would be useful in preventing postoperative stroke.

The sodium concentration in current crystalloid solutions varies widely. Whereas normal saline contains $154 \mathrm{mEq} / \mathrm{L}$ of $\mathrm{Na}^{+}$, lactated Ringer's and Plasma-Lyte solutions contain $130 \mathrm{mEq} / \mathrm{L}$ and $140 \mathrm{mEq} / \mathrm{L}$ of $\mathrm{Na}^{+}$, respectively. Therefore, a simple method of preventing hyponatremia during CPB is to avoid using low-sodium lactated Ringer's pump prime solution, especially in patients with preoperative hyponatremia. Although normal saline is a more logical choice of isotonic pump priming solution, recent literature associating hyperchloremia with increased 30-day mortality and longer hospital stays in noncardiac surgery raises questions about the wisdom of making a broad-based switch to normal saline. ${ }^{20}$ Thus, using a balanced Plasma-Lyte pump-priming solution may be ideal in patients with preoperative hyponatremia. Moreover, intraoperative hyponatremia during $\mathrm{CPB}$ may need to be treated quickly and properly (eg, by adding sodium bicarbonate).

\section{Study Limitations}

First, the study was retrospective and had the usual limitations associated with this design. Second, although we attempted to control for possible confounders by using multivariate logistic regression and propensity matching, unmeasured factors may have affected our results (eg, the extent and location of vascular atherosclerosis). Third, although the sodium content in lactated Ringer's solution $(130 \mathrm{mEq} / \mathrm{L})$ is relatively hyponatremic, that does not fully explain why some patients had an average serum sodium level less than $130 \mathrm{mEq} / \mathrm{L}$ during CPB. Indeed, these patients may have had a preexisting proclivity toward hyponatremia.

\section{CONCLUSIONS}

An average serum sodium level less than $130 \mathrm{mEq} / \mathrm{L}$ during CPB is independently associated with an increased risk of postoperative stroke in patients who undergo primary CABG. Further research is needed to determine whether maintaining a serum sodium level greater than $130 \mathrm{mEq} / \mathrm{L}$ during CPB may be beneficial in preventing postoperative stroke in cardiac surgery. 
Stephen N. Palmer, PhD, ELS, contributed to the editing of the article.

\section{References}

1. Tarakji KG, Sabik JF III, Bhudia SK, Batizy LH, Blackstone EH. Temporal onset, risk factors, and outcomes associated with stroke after coronary artery bypass grafting. JAMA. 2011;305:381-90.

2. Roach GW, Kanchuger M, Mangano CM, Newman M, Nussmeier N, Wolman R, et al. Adverse cerebral outcomes after coronary bypass surgery. Multicenter Study of Perioperative Ischemia Research Group and the Ischemia Research and Education Foundation Investigators. N Engl J Med. 1996;335:1857-63.

3. van Wermeskerken GK, Lardenoye JW, Hill SE, Grocott HP, Phillips-Bute B, Smith PK, et al. Intraoperative physiologic variables and outcome in cardiac surgery: Part II. Neurologic outcome. Ann Thorac Surg. 2000;69:1077-83.

4. Karkouti K, Djaiani G, Borger MA, Beattie WS, Fedorko L, Wijeysundera D, et al. Low hematocrit during cardiopulmonary bypass is associated with increased risk of perioperative stroke in cardiac surgery. Ann Thorac Surg. 2005;80:1381-7.

5. Hammon JW, Stump DA, Butterworth JF, Moody DM, Rorie K, Deal DD, et al. Single crossclamp improves 6-month cognitive outcome in high-risk coronary bypass patients: the effect of reduced aortic manipulation. J Thorac Cardiovasc Surg. 2006;131:114-21.

6. Pugsley W, Klinger L, Paschalis C, Treasure T, Harrison M, Newman S. The impact of microemboli during cardiopulmonary bypass on neuropsychological functioning. Stroke. 1994;25:1393-9.

7. Gold JP, Torres KE, Maldarelli W, Zhuravlev I, Condit D, Wasnick J. Improving outcomes in coronary surgery: the impact of echo-directed aortic cannulation and perioperative hemodynamic management in 500 patients. Ann Thorac Surg. 2004; 78:1579-85.

8. Gottesman RF, Sherman PM, Grega MA, Yousem DM, Borowicz LM Jr, Selnes OA, et al. Watershed strokes after cardiac surgery: diagnosis, etiology, and outcome. Stroke. 2006;37:2306-11.
9. Capes SE, Hunt D, Malmberg K, Pathak P, Gerstein HC. Stress hyperglycemia and prognosis of stroke in nondiabetic and diabetic patients: a systematic overview. Stroke. 2001;32:2426-32.

10. Leigh R, Zaidat OO, Suri MF, Lynch G, Sundararajan S, Sunshine JL, et al. Predictors of hyperacute clinical worsening in ischemic stroke patients receiving thrombolytic therapy. Stroke. 2004;35:1903-7.

11. Gleason VM, Martin ND. Intracranial hypertension secondary to psychogenic polydipsia. J Emerg Trauma Shock. 2012;5:193-5.

12. Barber GA, Whitefield JS. Cultivated child abuse: a 2-year-old with hyponatremic seizures. Pediatr Emerg Care. 2012;28:1234-5.

13. Warwick R, Palmer K, Johnson I, Poullis M. Preoperative hyponatremia and cardiopulmonary bypass: yet another factor for cerebral dysfunction? J Extra Corpor Technol. 2010;42:52-6.

14. Darzynkiewicz Z, Juan G, Li X, Gorczyca W, Murakami T, Traganos F. Cytometry in cell necrobiology: analysis of apoptosis and accidental cell death (necrosis). Cytometry. 1997;27:1-20.

15. McManus ML, Churchwell KB, Strange K. Regulation of cell volume in health and disease. N Engl J Med. 1995;333:1260-6.

16. Kvalheim VL, Rynning SE, Farstad M, Haugen O, Nygreen E, Mongstad A, et al Fluid overload during cardiopulmonary bypass is effectively reduced by a continuous infusion of hypertonic saline/dextran (HSD). Scand Cardiovasc J. 2008;42: 63-70.

17. Ayus JC, Armstrong D, Arieff AI. Hyponatremia with hypoxia: effects on brain adaptation, perfusion, and histology in rodents. Kidney Int. 2006;69:1319-25.

18. Ayus JC, Achinger SG, Arieff A. Brain cell volume regulation in hyponatremia: role of sex, age, vasopressin, and hypoxia. Am J Physiol Renal Physiol. 2008;295: F619-24.

19. Vexler ZS, Ayus JC, Roberts TP, Fraser CL, Kucharczyk J, Arieff AI. Hypoxic and ischemic hypoxia exacerbate brain injury associated with metabolic encephalopathy in laboratory animals. J Clin Invest. 1994;93:256-64.

20. McCluskey SA, Karkouti K, Wijeysundera D, Minkovich L, Tait G, Beattie WS Hyperchloremia after noncardiac surgery is independently associated with increased morbidity and mortality: a propensity-matched cohort study. Anesth Analg. 2013;117:412-21. 